\title{
How Principal Investigators' Commercial Experience Influences Technology Transfer and Market Impacts
}

James Cunningham

University of Northumbria at Newcastle, james.cunningham@northumbria.ac.uk

Brendan Dolan

National University of Ireland, Galway, brendan.dolan@nuigalway.ie

Matthias Menter

Friedrich Schiller University of Jena, matthias.menter@uni-jena.de

See next page for additional authors

Follow this and additional works at: https://arrow.tudublin.ie/buschmanart

Part of the Business Administration, Management, and Operations Commons

\section{Recommended Citation}

James A. Cunningham, Brendan Dolan, Matthias Menter, Conor O'Kane \& Paul O'Reilly (2020) How Principal Investigators' Commercial Experience Influences Technology Transfer and Market Impacts, Research-Technology Management, 63:5, 49-58, DOI: 10.1080/08956308.2020.1790244

This Article is brought to you for free and open access by the School of Management at ARROW@TU Dublin. It has been accepted for inclusion in Articles by an authorized administrator of ARROW@TU Dublin. For more information, please contact arrow.admin@tudublin.ie, aisling.coyne@tudublin.ie,gerard.connolly@tudublin.ie.

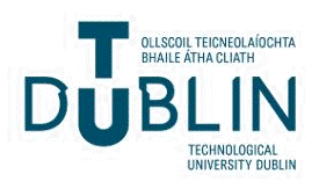




\section{Authors}

James Cunningham, Brendan Dolan, Matthias Menter, Conor O'Kane, and Paul O'Reilly 


\section{How Principal Investigators' Commercial Experience Influences Technology Transfer and Market Impacts}

James A. Cunningham, Brendan Dolan, Matthias Menter, Conor O'Kane \& Paul O’Reilly

To cite this article: James A. Cunningham, Brendan Dolan, Matthias Menter, Conor O'Kane \& Paul O'Reilly (2020) How Principal Investigators' Commercial Experience Influences Technology Transfer and Market Impacts, Research-Technology Management, 63:5, 49-58, DOI: 10.1080/08956308.2020.1790244

To link to this article: https://doi.org/10.1080/08956308.2020.1790244

曲 Published online: 08 Sep 2020.

Submit your article to this journal $\widetilde{T}$

Llll Article views: 139

Q View related articles $匚$

View Crossmark data 
FEATURE ARTICLE

\section{How Principal Investigators' Commercial Experience Influences Technology Transfer and Market Impacts}

In university-industry collaborations, a Pl's commercial experience and institutional supports can impact an industry partner's efforts to realize technology transfer and market impacts.

James A. Cunningham, Brendan Dolan, Matthias Menter, Conor O'Kane, and Paul O'Reilly

OVERVIEW: Businesses can benefit from university-industry collaborations, yet they rarely take full advantage of them. Scientists who serve as principal investigators (PIs) act as the nucleus of university-industry collaborations and partner with industry to cocreate value. We conducted a case study of PIs at publicly funded research universities, institutes, and organizations in Ireland to explore how having commercial experience influences how PIs approach technology transfer and how they develop new business models, products, and services. We learned that PIs' prior commercial experience influences how they approach their research, project work, and project selection and affects how they commercialize knowledge and outputs from their scientific research-that is, patents, licences, agreements, etc.-throughout the project's life cycle. In universityindustry collaborations, PIs' commercial experience can impact industry partners' attempts to realize technology transfer and market impacts.

KEYWORDS: Principal investigators, Technology transfer, Market impact, University-industry collaboration, Commercial experience

Innovations created by public research organizations such as universities or government research centers benefit industry (Giones 2019; Lehmann and Menter 2016; Tseng, Huang, and Chen 2020). Because the academic sector has proprietary knowledge and unique expertise and capabilities,

James A. Cunningham is a professor of strategic management at Newcastle Business School, Northumbria University, United Kingdom. His research intersects the fields of strategic management, innovation, and entrepreneurship. His research focuses on strategy issues with respect to scientists as principal investigators, university technology transfer commercialization, academic, public sector, and technology entrepreneurship, entrepreneurial universities, and business failure. Cunningham and his co-authors wish to acknowledge funding support of the Irish Research Council, CÚRAM Centre for Research in Medical Devices and Science Foundation Ireland (SFI) and co-funding under the European Regional Development Fund under Grant Number 13/RC/2073. james.cunningham@northumbria.ac.uk

Brendan Dolan is a postdoctoral researcher in the Principal Investigator Impact: Research in Medical Devices research program at CÚRAM Centre for Research in Medical Devices at National University of Ireland Galway, Ireland. His research interests include impact orientation theory, principal investigator research, applied ecological theory, and research process dynamics. brendan.dolan@nuigalway.ie

Matthias Menter is an assistant professor of business dynamics, innovation, and economic change at the Friedrich Schiller University Jena, Germany. $\mathrm{He}$

DOI: $10.1080 / 08956308.2020 .1790244$

Copyright (? 2020, Innovation Research Interchange.

Published by Taylor \& Francis. All rights reserved. university-industry collaborations can enhance businesses' innovation and technology development (Schoppe and Chylla 2016). Studies show that most university-industry research partnerships don't fully realize the value created during the collaborative process, due mainly to misaligned has also worked at the School of Public and Environmental Affairs (SPEA) at Indiana University-Bloomington, US, as a visiting scholar and adjunct lecturer. His research focuses on aspects of entrepreneurial and innovative ecosystems, academic entrepreneurship, university-industry collaborations, and public policy. Menter and his coauthors wish to acknowledge funding support from the Irish Research Council, CÚRAM Centre for Research in Medical Devices, and Science Foundation Ireland (SFI) and co-funding under the European Regional Development Fund under Grant Number 13/RC/2073. matthias. menter@uni-jena.de

Conor O'Kane is an associate professor and director of the Master of Entrepreneurship Program at Otago Business School, New Zealand. His research focuses on research commercialization, academic entrepreneurship, and the strategic role and behaviors of publicly funded principal investigators. $\mathrm{He}$ is an associate editor of the Journal of Management and Organization. He sat on the ANZAM Board for three years and served as chair of ANZAM's annual conference held in Queenstown, NZ, in 2015. conor.okane@otago.ac.nz

Paul O'Reilly is head of the School of Management, Technological University Dublin, Ireland. His research activities focus primarily on management of innovation, public research management, and research commercialization. He studies the role of principal investigators and how they strategize and develop research programs within public research systems. He has undertaken related consultancy assignments for Enterprise Ireland, the European Commission, Forfas, Royal Irish Academy, and Teagasc. paul.oreilly@tudublin.ie 
Technology transfer is an important part

of a PI's role, but Pls can face barriers

and feel unprepared for the

commercialization process.

\section{The Principal Investigator Role}

Companies make significant investments annually in university-industry collaborations to advance knowledge and create value through technology and knowledge transfer (Giunta, Pericoli, and Pierucci 2016; Freitas, Marques, and Silva 2013). Principal investigators lead large-scale research projects initiated by university-industry partnerships. Different definitions exist regarding who PIs are and what they do (Cunningham et al. 2014). O'Kane et al. (2017, p. 217) describe PIs as "lead researchers on successful programme and project grants," while Cunningham et al. (2016b, p. 72) define PIs as "scientists who orchestrate new research projects, combine resources and competencies, deepen existing scientific trajectories or shape new ones that are transformative in intent, nature and outcome that can be exploited for commercial ends and/or for societal common good." Boehm and Hogan (2014) suggest PIs have an entrepreneurial role in building and shaping networks as well as bridging the gap between science and industry.

Beyond teaching and administrative duties, PIs are influential research leaders who engage with industry partners, facilitate technology transfer, disseminate research, and manage resources (Cunningham et al. 2020; Romano, Schillaci, and Nicotra 2017). Casati and Genet (2014) argue that PIs take on more than scientific leadership and that often a disconnect exists between PIs' job descriptions and what they do in practice. According to Kidwell (2014, p. 34), PIs are at "the forefront of new scientific knowledge." Baglieri and Lorenzoni (2014) suggest that PIs play a pivotal role in technology transfer on the user side. Mangematin et al. (2014) state that PIs act as "linchpins" between science and markets. Hence, successful PIs have to boundary span-that is, collate and exchange information, knowledge, and know-how (Tushman and Scanlan 1981)between academic, industry, and policy sectors. PIs also have to collaborate with diverse academic and industry partners to realize technology and knowledge transfer outputs. In essence, they have to simultaneously combine academic rigor, commercialization, and value creation (Ambos et al. 2008).

\section{The PI's Role in Technology Transfer and Market Shaping}

To secure research funding with industry partners, PIs must make a compelling business case about the commercial and market potential of their scientific projects. PIs must be able to demonstrate market shaping-that is, use their scientific discoveries or knowledge to create new products, services, and business models that provide competitive advantage (Mangematin, O'Reilly, and Cunningham 2014). PIs also need to create value by leveraging their networks within and beyond academia through strong reciprocal interpersonal relationships (Cunningham, Menter, and O'Kane 2018). They must meet industry partners' expectations while concurrently meeting requirements to publish scientific results and pursue technology transfer opportunities (Cunningham, Menter, and Wirsching 2019).

Technology transfer is an important part of a PI's role, but PIs can face barriers and feel unprepared for the commercialization process. According to O'Kane et al. (2017), 
technology transfer offices (TTOs) lack much-needed market analysis resources to support PIs' commercialization and value creation efforts. This lack of support coupled with the power of industry partners (Cunningham et al. 2015) creates managerial challenges that impact the time that PIs allocate to their scientific projects. According to Cunningham et al. (2016a), PIs who allocated more time to research-related activities also allocated more of their time to technology transfer activities such as market research.

\section{The Case Study}

We surveyed PIs from publicly funded Irish-based universities, institutes of technology, and public research organizations in the fields of science, engineering, and technology. We identified 1,391 potential survey participants from public data on research projects and lead researchers, gathered from national funding agencies, organizations, and schemes, including Science Foundation Ireland, the Health Research Board, Enterprise Ireland, the Environmental Protection Agency, and the European Union Framework 6 and 7 schemes.

\section{Methodology}

Using Dillman's (2000) total design method, we emailed the potential PI respondents and asked them to complete an online survey. After three rounds of reminders, we had a response rate of 31.7 percent (441 valid responses).

This survey consisted of 40 predominantly closed-ended multiple-choice and ranking questions. The questions focused on PI activities and actions regarding the design, management, and promotion of their scientific projects. For most questions, we asked respondents to choose a publicly funded project on which they acted as a PI and answer in relation to this specific project. Given the exploratory nature of our study, we employed independent sample $t$-tests to examine statistically significant differences between PIs with and without previous commercial experience.

Respondents answered questions about industry collaboration and engagement, and motivation and control. We asked respondents about the extent to which they engaged in preproposal activities for their selected project, on a 7-point Likert scale, from not at all (1) to a very large extent (7). We also asked PIs about their level of involvement in different collaboration activities over the previous five years using a 3-point inverted scale from extensive involvement (1) to never involved (3).

Our survey also included questions about technology transfer and market impacts, and scientific publications and scientific capital impacts. We asked PI respondents to rate the level of importance placed on various impact criteria in their selected projects, on a 7-point Likert scale, from not important (1) to very important (7). Similarly, we asked PIs to assess the impact of their chosen project using a 7-point Likert scale, from no impact (1) to significant impact (7).

\section{Findings}

Thirty-three percent $(n=145)$ of respondents stated they had commercial experience (an average of five years of employment), compared to 67 percent $(n=296)$ with no commercial experience. For both groups' selected projects, approximately 30 percent were basic science projects, and approximately 70 percent were applied science projects. We grouped our findings according to collaboration focus and activities, impact focus, and determinants of university-industry project success.

\section{Collaboration Focus and Activities}

We found that PIs with commercial experience had higher levels of engagement in seven of the nine queried preproposal activities compared to PIs without commercial experience. The most significant differences between PIs with and without commercial experience were in desk research and direct consultation with industry end users, as well as patent searches (Table 1).

PIs with commercial experience ranked their top three factors that stimulated actual or potential technology transfer as strong linkages with industry, clearly defined commercialization opportunities, and institutional provision of technology transfer activities. By contrast, PIs without commercial experience ranked institutional provision of technology transfer activities highest, followed by own department leadership and commitment and strong linkages with industry (Table 2).

TABLE 1. Project preproposal activities

\begin{tabular}{|c|c|c|c|}
\hline Category & $\begin{array}{c}\text { Pls with commercial } \\
\text { experience }\end{array}$ & $\begin{array}{c}\text { Pls without commercial } \\
\text { experience }\end{array}$ & $\begin{array}{l}\text { Statistical } \\
\text { significance }\end{array}$ \\
\hline Patent search & $3.3 \pm 2.2$ & $2.5 \pm 2.1$ & 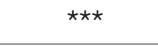 \\
\hline Literature search & $6.0 \pm 1.2$ & $6.1 \pm 1.4$ & ns \\
\hline Direct consultation with industry end users & $3.7 \pm 2.2$ & $2.7 \pm 1.9$ & 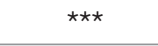 \\
\hline Direct consultation with technology transfer office & $3.0 \pm 2.0$ & $2.5 \pm 2.0$ & * \\
\hline Direct consultation with funding agency & $4.0 \pm 2.0$ & $3.4 \pm 2.0$ & ** \\
\hline Direct consultation with own institution scientific specialists & $4.2 \pm 2.2$ & $3.7 \pm 2.0$ & * \\
\hline
\end{tabular}

Note: The asterisks ${ }^{*},{ }^{*}$, and ${ }^{* \star *}$ indicate statistical significance at $5 \%, 1 \%$, and $0.1 \%$ alpha levels, respectively, using a two-tailed independent sample $t$-test-that is, ${ }^{*} p<0.05,{ }^{* *} p<0.01$, and ${ }^{* * *} p<0.001$. 
Regarding collaboration, PIs with commercial experience were more likely to be members of industry advisory boards or to undertake consultancy or contract assignments with private enterprises. However, we found no statistically significant differences between PIs with and without commercial experience regarding international collaboration.

Queried on a 7-point Likert scale from not at all (1) to a very large extent (7), PIs with commercial experience engaged in more preproposal consultation with scientific specialists in their own institution, whereas PIs without commercial experience focused more on academic partnerships and collaborations in general. Regarding their top three motivations for becoming a PI on their selected projects, PIs without commercial experience sought to increase their profile within internal and external research communities, though not to a significant degree (Table 3). By contrast, PIs with commercial experience wanted to become PIs on their selected projects to increase their control over technology transfer and administrative issues. We found that PIs without commercial experience focused more on creating and maintaining connections with internal and external research communities in their respective research field, whereas enhanced decision-making power, particularly with respect to technology transfer, motivated PIs with commercial experience.

\section{Impact Focus}

To examine potential differences between the intended and actual impact of their research projects, we asked respondents to first indicate the level of importance they placed

TABLE 2. Top three factors that facilitate actual or potential technology transfer for selected projects

\begin{tabular}{|c|c|}
\hline Pls with commercial experience & $\begin{array}{c}\text { Pls without commercial } \\
\text { experience }\end{array}$ \\
\hline 1) Strong industry linkages & $\begin{array}{l}\text { 1) Institutional provision of } \\
\text { technology transfer }\end{array}$ \\
\hline $\begin{array}{l}\text { 2) Clearly defined } \\
\text { commercialization opportunities }\end{array}$ & $\begin{array}{l}\text { 2) Own department } \\
\text { leadership and commitment }\end{array}$ \\
\hline $\begin{array}{l}\text { 3) Institutional provision of } \\
\text { technology transfer }\end{array}$ & 3) Strong industry linkages \\
\hline
\end{tabular}

on particular impact criteria (Table 4), and then assess the actual impact of their project in relation to these impact criteria (Table 5). PIs placed greater importance on scientific publications, scientific capital, and human capital impacts, compared to political and market impact. PIs with commercial experience rated technology transfer impact significantly higher than those without, which suggests they placed more emphasis on technology transfer compared to PIs without commercial experience. Although market impact was one of the least important impacts overall, PIs with commercial experience considered it significantly more important compared to those without commercial experience.

For their selected projects, PIs ranked scientific capital and human capital impacts highest. PIs with commercial experience rated technology transfer and market impacts significantly higher, which suggests they focused more on these two elements. On average, PIs with commercial experience had also filed more invention disclosures in the last five years. PIs without commercial experience reported that they focused more on scientific publications and scientific capital impacts. When asked to assess the actual impact of their chosen projects, PIs with commercial experience rated scientific capital impact and scientific publications lower than PIs without commercial experience. On average, PIs without commercial experience reported 20 peer-reviewed journal papers published in the last five years, compared to 18 for PIs with commercial experience.

For the selected projects, peer publication was the most common dissemination and technology transfer for PIs without commercial experience; PIs with commercial experience indicated that collaborative research with industry was the most common (Table 6). Our findings suggest that when designing their research projects, PIs without commercial experience put more focus on scientific impacts (peer publications), whereas PIs with commercial experience focus more on technology transfer and market impacts.

\section{Determinants of University-Industry Project Success}

When asked to rank the top three factors that determined a project's success, all PIs ranked the expertise of the project

TABLE 3. Motivations to become project PI

\begin{tabular}{|c|c|c|c|}
\hline Category & $\begin{array}{c}\text { Pls with commercial } \\
\text { experience }\end{array}$ & $\begin{array}{c}\text { Pls without commercial } \\
\text { experience }\end{array}$ & $\begin{array}{l}\text { Statistical } \\
\text { significance }\end{array}$ \\
\hline To have greater administrative control of project & $16.3 \%$ & $14.1 \%$ & ns \\
\hline To have greater scientific control of the project & $56.6 \%$ & $55.7 \%$ & ns \\
\hline To have greater administrative control of project budget & $8.5 \%$ & $9.8 \%$ & ns \\
\hline To increase profile within own institution & $31.8 \%$ & $34.9 \%$ & ns \\
\hline Requirement of my role in my institution & $24.8 \%$ & $25.9 \%$ & ns \\
\hline
\end{tabular}

Note: The asterisks ${ }^{*}$ and ${ }^{\star *}$ indicate statistical significance at $5 \%$ and $1 \%$ alpha levels, respectively, using a two-tailed independent sample t-test-that is, ${ }^{*} p<0.05$ and ${ }^{* *} p<0.01$ 
TABLE 4. Level of importance placed on impact criteria

\begin{tabular}{lccc}
\hline Category & $\begin{array}{c}\text { Pls with commercial } \\
\text { experience }\end{array}$ & $\begin{array}{c}\text { Pis without commercial } \\
\text { experience }\end{array}$ & Statistical significance \\
\hline Scientific publication & $5.9 \pm 1.5$ & $6.5 \pm 1.0$ & $4.4 \pm 1.9$ \\
\hline Technology transfer & $4.9 \pm 1.8$ & $4.1 \pm 1.9$ & $\mathrm{~ns}$ \\
\hline Political impact & $4.1 \pm 1.9$ & $4.5 \pm 1.7$ & $\mathrm{~ns}$ \\
\hline Economic impact & $4.4 \pm 1.8$ & $4.9 \pm 1.7$ & $\mathrm{~ns}$ \\
\hline Relationship impact & $4.8 \pm 1.7$ & $6.0 \pm 1.2$ & $\mathrm{~ns}$ \\
\hline Scientific capital impact & $5.8 \pm 1.2$ & $5.8 \pm 1.4$ & $\mathrm{~ns}$ \\
\hline Human capital impact & $5.7 \pm 1.5$ & $3.5 \pm 2.1$ & $\mathrm{~ns}$ \\
\hline Market impact & $4.2 \pm 2.1$ & $5.6 \pm 1.6$ & $\mathrm{~ns}$ \\
\hline Contract impact & $5.6 \pm 1.6$ & $\mathrm{n}$ & \\
\hline
\end{tabular}

Note: The asterisks * **, and ${ }^{* * *}$ indicate statistical significance at $5 \%, 1 \%$, and $0.1 \%$ alpha levels, respectively, using a two-tailed independent sample $t$-test--that is, ${ }^{*} p<0.05,{ }^{* *} p<0.01$, and ${ }^{* * *} p<0.001$.

TABLE 5. Self-assessment of impacts of selected projects

\begin{tabular}{lccc}
\hline Category & $\begin{array}{c}\text { Pls with commercial } \\
\text { experience }\end{array}$ & $\begin{array}{c}\text { Pls without commercial } \\
\text { experience }\end{array}$ & Statistical significance \\
\hline Scientific publication & $5.1 \pm 1.7$ & $5.7 \pm 1.3$ & $\mathrm{~ns}$ \\
\hline Technology transfer & $4.1 \pm 1.8$ & $3.8 \pm 1.9$ & $\mathrm{~ns}$ \\
\hline Political impact & $4.0 \pm 1.7$ & $4.0 \pm 1.8$ & $\mathrm{~ns}$ \\
\hline Economic impact & $4.5 \pm 1.6$ & $4.6 \pm 1.7$ & $\mathrm{~ns}$ \\
\hline Relationship impact & $4.8 \pm 1.7$ & $5.0 \pm 1.6$ & $\mathrm{~ns}$ \\
\hline Scientific capital impact & $5.6 \pm 1.3$ & $5.8 \pm 1.2$ & $\mathrm{~ns}$ \\
\hline Human capital impact & $5.6 \pm 1.3$ & $5.8 \pm 1.2$ & $\mathrm{~ns}$ \\
\hline Market impact & $3.7 \pm 2.0$ & $3.1 \pm 1.9$ & $5.5 \pm 1.5$ \\
\hline Contract impact & $5.4 \pm 1.6$ & $\mathrm{~ns}$ & \\
\hline
\end{tabular}

Note: The asterisks * ${ }^{* *}$, and *** indicate statistical significance at $5 \%, 1 \%$, and $0.1 \%$ alpha levels, respectively, using a two-tailed independent sample t-test-that is, ${ }^{*} p<0.05,{ }^{* *} p<0.01$, and ${ }^{* * *} p<0.001$.

team first, followed by a strong project leader, and effective project planning. We also asked PIs to rank the top three factors that stimulated actual or potential technology transfer on their selected projects. PIs with commercial experience ranked industry linkages and clearly defined commercialization opportunities significantly higher, while PIs without commercial experience emphasized the role of their own department, the technology transfer office, and perhaps most significantly, institutional provision of technology transfer activities (Table 7). At the same time that PIs without commercial experience sought greater autonomy on their research projects, they relied more heavily on institutional supports for their technology transfer activities.

In summary, our results suggest that PIs without commercial experience focused on publications and relied on the technology transfer office for their technology transfer activities. In contrast, PIs with previous commercial experience focused more on knowledge creation and a research idea's commercial potential.

\section{Discussion}

We explored whether PIs' prior commercial experience influences their approaches to technology transfer and market impacts in university-industry collaborations. We found that commercial experience influences research approaches, project work, and project selection. We also found that PIs without commercial experience focused on scientific publications and scientific capital, while PIs with prior commercial experience focused more on technology transfer and market impacts.

Our results suggest that PIs with commercial experience engaged more with industry partners from project inception through planning to the dissemination phase. They were more likely to form strong linkages with industry and bring in additional industry partners or industry contributors to their research projects. Overall, PIs with prior commercial experience further prioritized matching the project scope with industry demand compared to PIs without commercial experience; this emphasis may mean that projects run by PIs with commercial experience will result in more tangible outcomes and commercial success.

By contrast, PIs without commercial experience prioritized scientific capital impacts as reflected by their focus on scientific publications and their motivation to increase their profile within external research communities. 
TABLE 6. Most common dissemination and technology transfer activity on selected projects

\begin{tabular}{lccc}
\hline Category & $\begin{array}{c}\text { Pls with commercial } \\
\text { experience }\end{array}$ & $\begin{array}{c}\text { Pls without commercial } \\
\text { experience }\end{array}$ & $\begin{array}{c}\text { Statistical } \\
\text { significance }\end{array}$ \\
\hline Industry workshops & $7.3 \%$ & $4.7 \%$ & $\mathrm{~ns}$ \\
\hline Research symposiums and colloquiums & $14.6 \%$ & $18.6 \%$ & $\mathrm{~ns}$ \\
\hline Peer publications & $38.2 \%$ & $52.6 \%$ & $\mathrm{~ns}$ \\
\hline End-of-project reports & $12.2 \%$ & $11.5 \%$ & \\
\hline Collaborative research with industry & $12.2 \%$ & $4.3 \%$ & $\mathrm{~ns}$ \\
\hline Contractual research for industry & $1.6 \%$ & $2.0 \%$ & \\
\hline Consulting and technical services & $4.9 \%$ & $1.2 \%$ & $\mathrm{~ns}$ \\
\hline Licensing of intellectual property & $4.1 \%$ & $3.2 \%$ & $\mathrm{~ns}$ \\
\hline Spin-off enterprise & $4.9 \%$ & $2.0 \%$ & $\mathrm{~ns}$ \\
\hline
\end{tabular}

Note: The asterisks ${ }^{*},{ }^{* *}$, and ${ }^{* \star *}$ indicate statistical significance at $5 \%, 1 \%$, and $0.1 \%$ alpha levels, respectively, using a two-tailed independent sample $t$-test-that is, ${ }^{*} p<0.05,{ }^{* *} p<0.01$, and ${ }^{* * *} p<0.001$.

TABLE 7. Factors that facilitate technology transfer

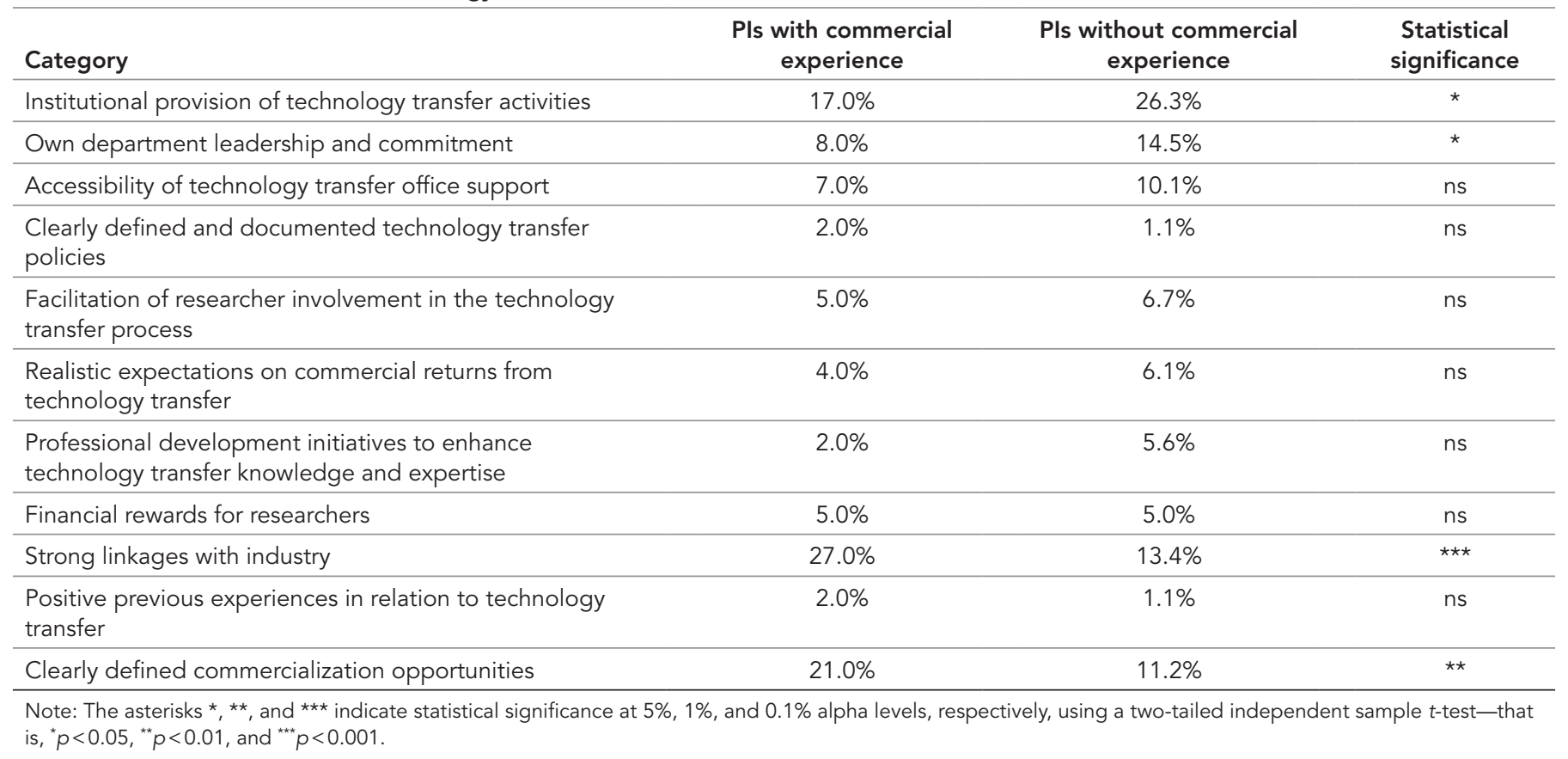

Overall, PIs without prior commercial experience relied more on institutional support structures for their technology transfer activities. Hence, industry partners should consider these dependencies and offer additional support in cases where institutional support structures are insufficient.

Our study offers practical considerations for industry partners looking to engage in university-industry collaborations. Industry partners may favor PIs with commercial experience due to their experience edge-they may believe that these PIs can more adeptly exploit knowledge and technology transfer opportunities because they understand the industry partner's needs and market opportunities better. Industry partners may hesitate to engage with PIs without commercial experience due to their reliance on institutional supports for technology transfer activities. Since the level of technology transfer supports varies between institutions, it can influence the project work of individual academic scientists (Braunerhjelm 2007; Lawson and Sterzi 2014). If PIs do not receive adequate institutional support (mentoring and nurturing) to mitigate their lack of commercial experience (Cunningham et al. 2014), neither the PIs, nor their institution, nor their industry partners may fully realize opportunities from technology transfer. Therefore, the level of institutional support given to PIs could be a determining factor for industry partners.

PIs both with and without commercial experience can enhance scientific and technological progress. PIs with commercial experience are not necessarily better collaboratorsthe best choice for an industry partner depends on which project approach it deems will prove most beneficial. Regardless, the project design stage is the best time for 
industry partners and project PIs to agree upon a strategy that will foster the creation of new knowledge and promote optimal technology transfer outcomes.

Industry partners can proactively support PIs without commercial experience by engaging with their institutional supports such as TTOs. If industry partners engage with institutional supports at the project design stage, the collaborators may be able to avoid technology transfer obstacles and maximize value. We recommend that institutional support structures such as technology transfer offices be used irrespective of PIs' commercial experience, as the PIs in our study tended to favor knowledge transfer (publications, end-of-project reports) over more formal technology transfer outputs (spin-off firms, licenses). Institutional support structures are beneficial and should be used to guide the activities of PIs. Industry partners should work closely with PIs at every stage of a funded project to ensure they secure their desired outcomes-that is, the transformation of scientific research into commercializable knowledge such as patents, licences, agreements, etc.

PIs and industry partners should align their knowledge and technology transfer strategy to exploit new knowledge. Having mutual, clearly defined commercialization objectives at the outset may spur technology transfer. Industry partners need to recognize that in university-industry collaborations PIs are motivated by creating new knowledge and scientific publications and may be less focused on having control over the technology transfer process. Industry partners' engagement and partnership strategies with PIs should build a common purpose that meets this core motivation of creating new knowledge.

To be effective within university-industry collaborations, PIs need the appropriate skills and capabilities to be successful (Cunningham et al. 2015). Academic and research institutions need to create environments in which PIs can thrive and achieve technology transfer so their industry partners can achieve a dominant market position (Dolan et al. 2019; Kidwell 2014). Industry partners have an explicit expectation that PIs will contribute to technology transfer and market benefits. To make better use of their university-industry collaborations, companies must carefully select their PIs and consider potential barriers to technology and knowledge transfer (Albats, Fiegenbaum, and Cunningham 2018).

PIs with commercial experience may understand industry partners' needs, but PIs without commercial experience might challenge status quo thinking and approaches and open up new research paths. For PIs and industry partners, our study reinforces the need for strong institutional support to bring about more effective technology transfer. This support could include having commercialization and sectoral expertise within a TTO, robust technology transfer policies and procedures (invention disclosure processes, standard technology transfer agreements for licensing), and funding to support legal and other professional development support in cases of technology transfer disputes. Inadequate institutional technology transfer supports can hamper technology transfer efforts, destroy value created within
Pls both with and without commercial

experience can enhance scientific and

technological progress ... the best

choice for an industry partner depends

on which project approach it deems will

prove most beneficial.

university-industry collaborations, and potentially deter or turn off industry partners.

Some limitations of our study are worth noting. As PIs completed this survey based on their own assessments, there is some risk of self-reporting bias. In addition, our sample consisted of PIs in Ireland, which may limit the generalizability of our results; the respective academic context and the country's associated higher education legislation might impact PIs' research activities (Cunningham et al. 2019).

\section{Conclusion}

When selecting a PI for university-industry collaborations, industry partners should consider several factors. PIs with commercial experience may be attractive because they may be more effective at knowledge and technology transfer and creating outputs with market impact. However, industry partners shouldn't necessarily disregard PIs without commercial experience, because they may challenge the status quo and forge new research opportunities with valuable technology and market potential. The technology transfer support that the PI's institution offers is an important consideration because inadequate support can mean loss of knowledge and untapped value creation. Industry partners thereby have an opportunity to create a more fertile environment by providing more dedicated structures and support mechanisms for PIs with and without commercial experience and to overcome existing barriers that hinder efficient technology transfer processes.

\section{References}

Albats, E., Fiegenbaum, E. I., and Cunningham, J. A. 2018. A micro level study of university industry collaborative lifecycle key performance indicators. Journal of Technology Transfer 43(2): 389-431. doi:10.1007/s10961-017-9555-2

Ambos, T., Makela, K., Birkensaw, J., and D’Éste, P. 2008. When does university research get commercialized? Creating ambidexterity in research institutions. Journal of Management Studies 45(8): 1425-47. doi:10.1111/j.1467-6486.2008. 00804.X

Baglieri, D., and Lorenzoni, G. 2014. Closing the distance between academia and market: experimentation and user entrepreneurial processes. Journal of Technology Transfer 39(1): 52-74. doi:10.1007/s10961-012-9274-7 
Boehm, D. N., and Hogan, T. 2014. 'A jack of all trades': The role of PIs in the establishment and management of collaborative networks in scientific knowledge commercialization. Journal of Technology Transfer 39(1): 134-49. doi:10.1007/ s10961-012-9273-8

Braunerhjelm, P. 2007. Academic entrepreneurship: social norms, university culture and policies. Science and Public Policy 34(9): 619-31. doi:10.3152/030234207X276554

Casati, A., and Genet, C. 2014. Principal investigators as scientific entrepreneurs. The Journal of Technology Transfer 39(1): 11-32. doi:10.1007/s10961-012-9275-6

Cunningham, J. A. 2019. Principal investigators and boundary spanning entrepreneurial opportunity recognition: a conceptual framework. In A Research Agenda for Entrepreneurship and Innovation, ed. D. B. Audretsch, E. E. Lehmann and A. N. Link, 55-73. Cheltenham, UK: Edward Elgar.

Cunningham, J. A., and Harney, B. 2006. Strategic Management of Technology Transfer: The New Challenge on Campus. Oxford, UK: Oak Tree Press.

Cunningham, J. A., Lehmann, E. E., Menter, M., and Seitz, N. 2019. The impact of university focused technology transfer policies on regional innovation and entrepreneurship. Journal of Technology Transfer 44(5): 1451-75. doi:10.1007/ s10961-019-09733-0

Cunningham, J. A., Menter, M., and O'Kane, C. 2018. Value creation in the quadruple helix: a micro level conceptual model of principal investigators as value creators. ReD Management 48(1): 136-47. doi:10.1111/radm.12310

Cunningham, J. A., Menter, M., and Wirsching, K. 2019. Entrepreneurial ecosystem governance: a principal investigator-centered governance framework. Small Business Economics 52(2): 545-62. doi:10.1007/s1 1187-017-9959-2

Cunningham, J. A., and O'Reilly, P. 2019. Roles and Responsibilities of Project Coordinators: A Contingency Model for Project Coordinator Effectiveness. JRC Working Papers, JRC117576.

Cunningham, J. A., O'Reilly, P., Dolan, B., O'Kane, C., and Mangematin, V. 2016a. Publicly funded principal investigators allocation of time for public sector entrepreneurship activities. Economia e Politica Industriale 43(4): 383-408. doi:10.1007/s40812-016-0054-5

Cunningham, J. A., O'Reilly, P., Dolan, B., O'Kane, C., and V. Mangematin, V. 2017. Gender different and academic entrepreneurship: A study of scientists in the principal investigator role. In Gender and Entrepreneurial Activity, ed. A. N. Link, 221-51. Cheltenham, UK: Edward Elgar.

Cunningham, J. A., O'Reilly, P., O'Kane, C., and Mangematin, V. 2014. The inhibiting factors that principal investigators experience in leading publicly funded research. Journal of Technology Transfer 39(1): 93-110. doi:10.1007/s10961012-9269-4

Cunningham, J. A., O'Reilly, P., O'Kane, C., and Mangematin, V. 2015. Managerial challenges of publicly funded principal investigators. International Journal of Technology Management 68(3-4): 176-202. doi:10.1504/IJTM.2015.069669

Cunningham, J. A., O'Reilly, P., O'Kane, C., and Mangematin, V. 2016b. Publicly funded principal investigators as transformative agents of public sector entrepreneurship. In Essays in Public Sector Entrepreneurship, ed. D. B. Audretsch and A. N. Link, 67-94. Cham, Switzerland: Springer.

Cunningham, J. A., O'Reilly, P., Hooper, D., Nepelski, D., and Van Roy, V. 2020. The Role of Project Coordinators in European
Commission Framework Programme Projects. Publications Office of the European Union, Luxembourg (JRC120015). doi:10.2760/709126

Del Giudice, M., Nicotra, M., Romano, M., and Schillaci, C. E. 2017. Entrepreneurial performance of principal investigators and country culture: Relations and influences. Journal of Technology Transfer 42(2): 320-37. doi:10.1007/s10961-0169499-y

Dillman, D. 2000. Constructing the Questionnaire. Mail and Internet Surveys. New York, NY: John Wiley \& Sons.

Dolan, B., Cunningham, J. A., Menter, M., and McGregor, C. 2019. The role and function of cooperative research centers in entrepreneurial universities: A micro level perspective. ManagementDecision57(12):3406-25.doi:10.1108/MD-10-20181172

Freitas, I. M. B., Marques, R. A., and Silva, E. M. D. P. 2013. University-industry collaboration and innovation in emergent and mature industries in new industrialized countries. Research Policy 42(2): 443-53. doi:10.1016/j.respol.2012.06. 006

Giones, F. 2019. University-industry collaborations: An industry perspective. Management Decision 57(12): 3258-79. doi:10.1108/MD-11-2018-1182

Giunta, A., Pericoli, F. M., and Pierucci, E. 2016. Universityindustry collaboration in the biopharmaceuticals: The Italian case. Journal of Technology Transfer 41 (4): 818-40. doi:10.1007/ s10961-015-9402-2

Kastrin, A., Klisara, J., Lužar, B., and Povh, J. 2018. Is science driven by principal investigators? Scientometrics 117(2): 1157 82. doi:10.1007/s1 1192-018-2900-X

Kidwell, D. 2014. Navigating the role of the principal investigator: A comparison of a comparison of four cases. Journal of Technology Transfer 39(1): 33-51. doi:10.1007/s10961-0129276-5

Lawson, C., and Sterzi, V. 2014. The role of early-career factors in the formation of serial academic inventors. Science and Public Policy 4l (4): 464-79. doi:10.1093/scipol/sct076

Lehmann, E. E., and Menter, M. 2016. University-industry collaboration and regional wealth. Journal of Technology Transfer 41 (6): 1284-307. doi:10.1007/s10961-015-9445-4

Mangematin, V., O'Reilly, P., and Cunningham, J. A. 2014. PIs as boundary spanners, science and market shapers. Journal of Technology Transfer 39(1): 1-10. doi:10.1007/s10961-0129270-y

McConnell, D. P., and Cross, S. E. 2019. Realizing the value of industry-university innovation alliances. Research-Technology Management 62(2): 40-48. doi:10.1080/08956308.2019.156 3437

Menter, M. 2016. Principal Investigators and the commercialization of knowledge. In University Evolution Entrepreneurial Activity and Regional Competitiveness, ed. D. B. Audretsch, E. E. Lehmann, S. Vismara, and M. Meoli, 193-203. Heidelberg, Germany: Springer.

O'Kane, C. 2018. Technology transfer executives' backwards integration: An examination of interactions between university technology transfer executives and principal investigators. Technovation 76: 64-77. doi:10.1016/j.technovation.2016. 08.001

O'Kane, C., Zhang, J. A., Cunningham, J. A., and O'Reilly, P. 2017. What factors inhibit publicly funded principal investigators' commercialization activities? Small Enterprise Research 24(3): 215-32. doi:10.1080/13215906.2017.1396558 
Romano, M., Schillaci, E. C., and Nicotra, M. 2017. Principal investigators in entrepreneurial universities-A research framework. In The World Scientific Reference on Entrepreneurship, ed. J. A. Cunningham, M. Guerrero, and D. Urbano, 165-84. Singapore: World Scientific Publishing.

Schoppe, L. A., and Chylla, R. W. 2016. Collaborating with universities and government labs. Research-Technology Management 59(1): 67-71. doi:10.1080/08956308.2016.1117356

Starbuck, E. 2001. Optimizing university research collaborations. Research-Technology Management 44(1): 40-44. doi:10.1080/ 08956308.2001.11671406
Tseng, F. C., Huang, M. H., and Chen, D. Z. 2020. Factors of university-industry collaboration affecting university innovation performance. Journal of Technology Transfer 45:560-77. doi:10.1007/s10961-018-9656-6

Tushman, M. L., and Scanlan, T. J. 1981. Characteristics and external orientations of boundary spanning individuals. Academy of Management Journal 24(1): 83-98. doi:10.2307/ 255825

Valentín, E. M. M. 2000. University-industry cooperation: A framework of benefits and obstacles. Industry and Higher Education 14(3): 165-72. doi:10.5367/000000000101295011

HERE'S WHERE THE TALENT IS FOUND.

\section{THE IRI CAREER CENTER IS YOUR ONLINE RESOURCE FOR QUALIFIED R\&D AND INNOVATION \\ PROFESSIONALS. is

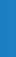

EXPERIENCED | QUALIFIED | TALENTED

IRI Career Center is the exclusive resource for candidates who specialize in R\&D and Innovation. The system offers you an extensive resume database and powerful, user-friendly searching capabilities that allow you to find the candidates that you need to meet your organizations recruitment goals. To find out why over hundreds rely on the IRI Career Center to fill their positions, visit us today!
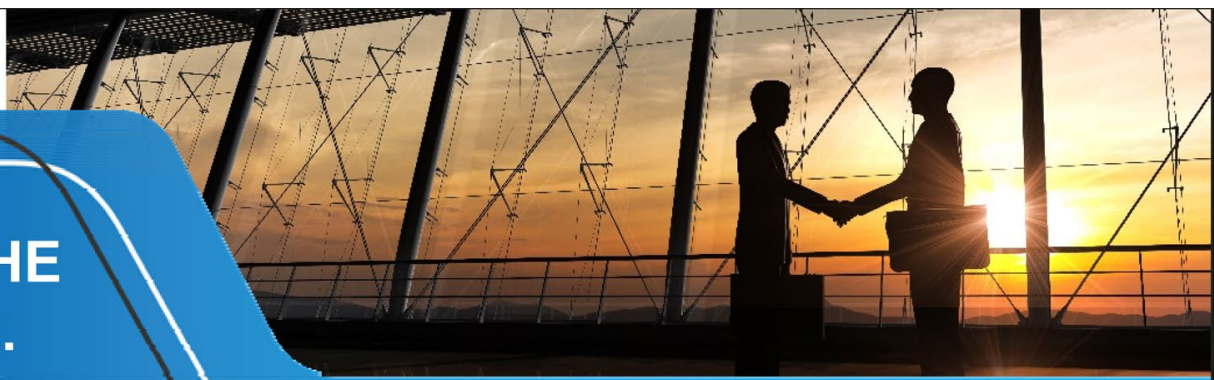


\section{THE INNOVATION}

RESEARCH

INTERCHANGE IS WHERE TALENT IS FOUND

THE IRI CAREER CENTER

IS YOUR ONLINE

RESOURCE FOR

QUALIFIED R\&D AND INNOVATION

PROFESSIONALS
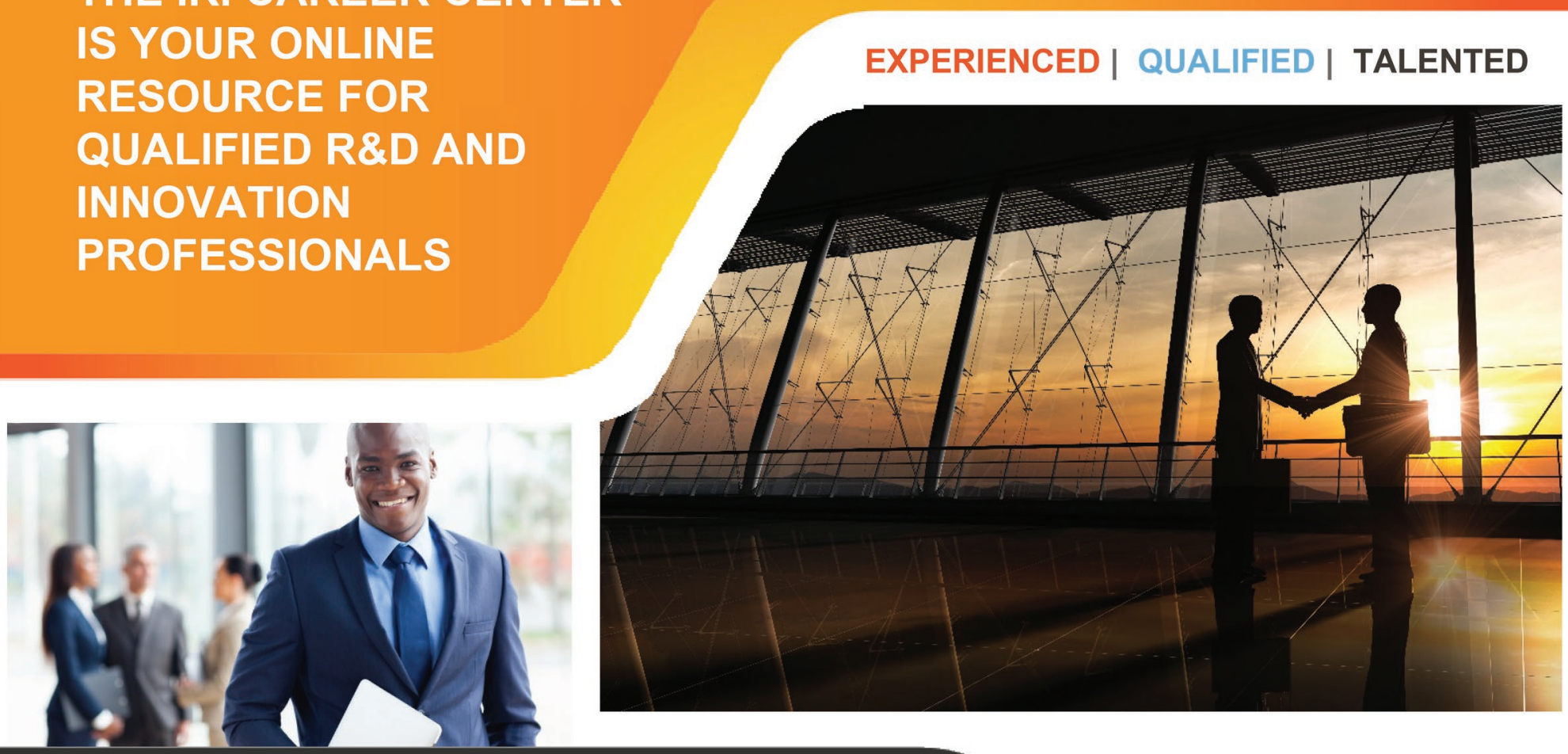

IRI Career Center is the exclusive online resource for candidates in the R\&D and Innovation industry. The system offers you an extensive resume database and powerful, user-friendly searching capabilities that allow you to find the candidates that you need to meet your organizations recruitment goals.

As a part of the Engineering and Science Career Network, you'll have access to 85,000 top quality candidates. Visit the IRI Career Center today!

\section{EMPLOYER RESOURCES}

-TARGETED ADVERTISING

-FULL RESUME ACCESS

- JOB ACTIVITY REPORTS

-ADVERTISING ENHANCEMENTS

-EMAIL NOTIFICATIONS

-MEMBER DISCOUNTS 